\title{
Molecular Cloning of Bovine CD14 gene
}

\author{
Akemi IKEDA, Masuhiro TAKATA ${ }^{1) *}$, Takahide TANIGUCHI, and Kenji SEKIKAWA ${ }^{1)}$ \\ Institute of Society for Techno-Innovation for Agriculture, Forestry and Fisheries, 446-1 Ipponzuka, Tsukuba, Ibaraki 305 and \\ ${ }^{1}$ National Institute of Animal Health, 3-1-1 Kannondai, Tsukuba, Ibaraki 305, Japan \\ (Received 14 February 1997/Accepted 16 April 1997)
}

ABSTRACT. Genomic DNA encoding bovine CD14 was isolated from a bovine (Holstein) genomic library. Utilizing PCR fragment of mouse CD14 gene as a probe, we screened $9 \times 10^{5}$ plaques and obtained 3 clones containing the bovine CD14 gene. DNA sequencing showed that bovine CD14 gene encodes 373 amino acids, and the coding sequence was separated by a 90 nt intron. The identity of the deduced amino acid sequence of bovine CD14 was $61-73 \%$ to those of mouse, rabbit and human. Northern blot analysis revealed that CD14 mRNA $(1.5 \mathrm{~kb})$ was expressed in the lung. Expression of CD14 mRNA was stimulated about 2-fold in bovine peripheral blood macrophage activated with LPS in vitro.-KEY wORDs: bovine, CD14, genomic DNA cloning.

J. Vet. Med. Sci. 59(8): 715-719, 1997

CD14 is a myeloid membrane glycoprotein which serves as a receptor for complexes of lipopolysaccharide (LPS) and LPS-binding protein (LBP) [13, 16, 19]. Most prominent cellular response for LPS is that monocytes and macrophages extensively produce pro-inflammatory cytokines such as IL-1 $\alpha, \beta$ and TNF $\alpha[1,12,18,19]$. The precise mechanisms of LPS-LBP signal transduction via CD14 receptor is yet unclear. Since CD14 is a glycosylphosphatidylinositol-anchored protein and lacks the intracellular sequence required for signaling, CD14associated transducing molecules may be required for LPS signaling [6, 19]. Functional roles of CD14 receptor have been suggested in endotoxemia, sepsis and inflammatory diseases $[4,9,13,19]$. To investigate the mechanism of LPS-signal-transduction and regulation of CD14 mRNA expression in bovine, we report here the cloning and the nucleotide sequence of bovine CD14 genomic gene.

We amplified a part of mouse CD14 gene (1416-1706 nt position [11]) and used as a probe. PCR was performed in a TAKARA Thermal Cycler PJ-480 for 30 cycles at $94^{\circ} \mathrm{C}$ for $1 \mathrm{~min}, 53^{\circ} \mathrm{C}$ for $1.5 \mathrm{~min}$ and $72^{\circ} \mathrm{C}$ for $1.5 \mathrm{~min}$. The final volume of $100 \mu \mathrm{l}$ contained $1 \mu \mathrm{g}$ of C57BL6J mouse genomic DNA, 10mM Tris- $\mathrm{HCl}(\mathrm{pH} 8.3), 50 \mathrm{mM} \mathrm{KCl}, 2.5$ $\mathrm{mM} \mathrm{MgCl}_{2}, 200 \mu \mathrm{M}$ dNTP, $1 \mu \mathrm{M}$ sense primer (5'AGACCTGTCTGACAATCCTG-3'), $1 \mu \mathrm{M}$ anti-sense primer (5'-TTGGCTGGCAGCCCTTTAGG-3') and 2.5 units of AmpliTaq DNA polymerase (Perkin-Elmer). A PCR product of approximately $300 \mathrm{bp}$ was obtained, and labeled with $\left[\alpha^{-32} \mathrm{P}\right] \mathrm{dCTP}(3000 \mathrm{Ci} / \mathrm{mmol}, \mathrm{NEN})$ by random primer labeling kit (Amersham). A bovine genomic DNA library was purchased from CLONTECH (cat. \#BL 1015j), and approximately $10^{6}$ plaques of the library were plated and transferred to nylon filters (Colony/Plaque Screen; NEN). They were hybridized with the $\left[\alpha-{ }^{32} \mathrm{P}\right]$ dCTP-labeled probe for $20 \mathrm{hr}$ at $65^{\circ} \mathrm{C}$ in hybridization mix (1\% SDS, $1 \mathrm{M}$ $\mathrm{NaCl}, 10 \%$ dextran sulfate, $100 \mu \mathrm{g} / \mathrm{m} l$ salmon sperm DNA).

* Correspondence to: Takata, M., National Institute of Animal Health, 3-1-1 Kannondai, Tsukuba Ibaraki 305, Japan. The nucleotide sequence(s) reported in this paper has been submitted to the DNA Data Bank of Japan (DDBJ) with accession number(s) D84509.
After being washed twice with $2 \mathrm{XSSC} / 1 \%$ SDS for $15 \mathrm{~min}$ at $60^{\circ} \mathrm{C}$, the filters were exposed to an Imaging Plate (Fuji Photo Film Co., Ltd.). Three positive clones were obtained, and these three genomic DNAs were digested by XhoI and $7.5 \mathrm{~kb}$ fragment were subcloned into XhoI-digested pBluescript SK $\mathrm{II}^{+}$for sequencing.

DNA sequences were determined by the dideoxy nucleotide chain termination method on a DNA sequencer 373S (Applied Biosystems). The sequences were obtained for both strands. Sequence analysis was performed with Genetyx-Mac software (Software Development Co., Ltd.). Three clones have identical sequence each other within ATG initiation codon to TAA stop codon, one of three clone was sequenced throughly. CD14 genomic DNA sequence is shown in Fig. 1. Splice donor/acceptor sites were confirmed by sequencing of RT-PCR products (data not shown). Coding region was $1119 \mathrm{nt}$ in length, and a $90 \mathrm{nt}$ intron was present just behind an ATG initiation codon. This gene organization is similar to those of other species $[2,3,8,11]$ and its coding sequence was highly homologous to mouse $[3,11,14]$, human $[2,15]$ and rabbit [8] CD14 cDNAs. We could not determine the strict position of the transcription initiation site and polyadenylation signals, mouse CD14 cDNA have about 110 bp of 5' untranslated region and about 80 bp or 220 bp of 3' untranslated region [3, 11].

The deduced amino acid sequence of bovine CD14 was compared and aligned with those of three other mammalian species (Fig. 2). As shown in Table 1, the number of amino acids in bovine CD14 was 373 and the identities between the amino acid sequences of bovine CD14 and the other three mammalian species were $61-73 \%$.

The distribution of the CD14 transcripts was investigated by RT-PCR of poly(A) ${ }^{+}$RNA from the kidney, lung, brain and liver (Fig. 3). Reverse transcription was carried out with MuLV-RT (Perkin-Elmer) and oligo(dT) $)_{16}$ and PCR was performed in TAKARA Thermal Cycler TP-3000 for 30 cycles at $94^{\circ} \mathrm{C}$ for $1.5 \mathrm{~min}, 64^{\circ} \mathrm{C}$ for $1.5 \mathrm{~min}$ and $74^{\circ} \mathrm{C}$ for $1.5 \mathrm{~min}$. The reaction mixture $(100 \mu l)$ contained 500 $n \mathrm{~g}$ of cDNA, $10 \mathrm{mM}$ Tris- $\mathrm{HCl}(\mathrm{pH} 8.3), 50 \mathrm{mM} \mathrm{KCl}, 2.5$ $\mathrm{mM} \mathrm{MgCl}_{2}, 200 \mu \mathrm{M}$ dNTP, $0.2 \mu \mathrm{M}$ of sense primer (5'TCCAGCCGACAACCAGAGAGA-3'), $0.2 \mu \mathrm{M}$ of anti-sense primer (5'-AAGGCTGGTTGGTTGAGATGTC- 
agagagtgaggcactaggccaatgtgtctctgttcaacacatagacttctctacttt aa gaa a ctgttactttaa a attgtgaatcaccacattgcacacctgttacacgta acatt gtacatcaattatact tcat t taa a a a tctatcaggattaccttctcctaagacaca cctggagaaggcalggcaacccactccagtattctagcctggaaatcccaaggacaga ggagcctggtaggctgcagtccatggggttgctaggagttggacaggactgagcgacttc act tcactetcact tcatgcattggagaagggaatggcaacccactccagtggtctt gcctggagaatcccagggaaggggg gcctggtgGgctgcegtctatggggtcacacagag ccagacacalctgaggtgact agtagcagcagcagcgagacacaccaa a ctggccat ga agatelccaetglgtctgtaactecctggtggtccagtggttaagactgcactccca clgcagg gtgt gacatca

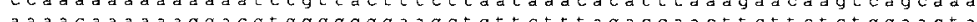
a a a caa a a a g gacgtgggggggaagctgttctttagaccaact tct tctctgga acta tgag

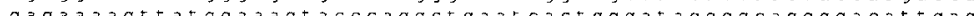
gaga a a getatggaa gtacccaggctga atcactgggataggggcaggggacattgag a atcotggoctgagga getaggaatctcctetect ctgatcacet got goctgogaggaga

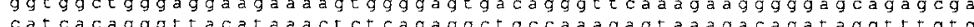
catcaca gat agagagagaggcagaggctctgagaatctaccgactatggtgagagtatgttcttggggc

1321

1381

1441

1501

1561

1621

1681

1742

1802

1861

1927

1981

2041

2101

2161

2221

2281

2342

2401

2461

252

250

264

270

276

282

2881
2941

Fig. 1. Nucleotide and deduced amino acid sequences of bovine CD14 gene. The potential polyadenylation signals are underlined.

tctttccaggtgrgcgtgccctacctgctgctgctgctgetgccgtcactgctgcgtgtg

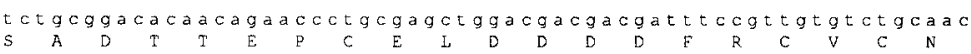

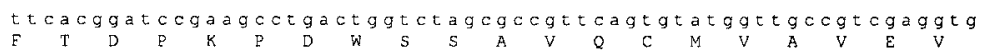
gagatcagtgccggcggccgcagcctggaacagtetctcaggggagcegacaccaacccg aagcagtatgctgacacaatcaaggctctgcgcgtccggcgactcaggctgggcgctgca $\underset{Q}{c a g g c t c c t g c t c a g c t t c t g g t c g c c g t t c t g c g c g c g c t c g g g t a c t c t c g t c t c a a g}$ gaactgacgcttgaggacetggaggtaaccggcceaacgececegacgcetctggaagcc gctgggcctgcgctcaccaccetcagtctccgtaacgtatcgtggacaacaggaggtgcc tggctcggcgaactgcagcagcggctcaagcetgggctcagggtgctgaacatcgcccaa gcacactcgcttgcetetcegtgcgcagggctctccaccttcgaggcoctcaccacecta $\underset{D}{g a c c t g t c t g a c a a t c c c a g t c t c g g c g a c a g c g g g c t g a t g g c a g c t c t c t g t c c g a a c}$

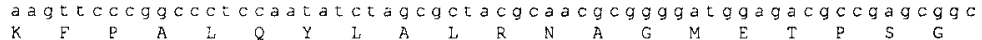
$\underset{V}{g t g t g c g c g g c g c t g g c g g c a g c g a g g g t g c a g c c c c a a g g c c t g g a c c t c a g c c a c a c}$ $\underset{S}{t} \operatorname{coctgcgcgtcaccgccccgggtgctacccgatgcgtctggcccagtgcactaaggtct}$ ctcaatttgtcgttcgctgggctggagcaagtgcctagggactgcccectaagctcagc

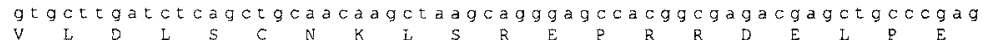

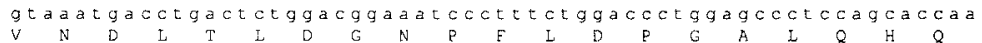

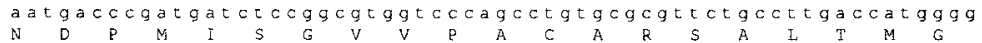

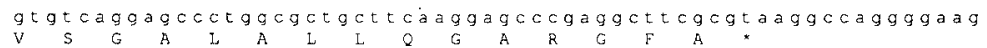
agagggaagaggaatgaattggctcagat tgccctggctccgggagaccctcgccaggac atctcaaccaaccagcctcctaccccat c cttattaaa $\operatorname{cogta} a \mathrm{acagcagatccgtgt}$ cattgactcagcagatgettactgggcacagtgctggacagggaatccattatacttaa a

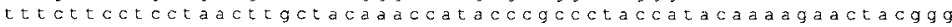

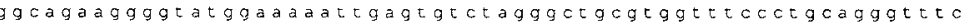
ctgccatt tggggtt tetga acagat tactaca acctgtgttaaaggatgtt tgattg

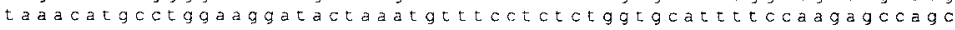
cagctgctccetctocaaggtaataaacccagaggcatttgct attctiac 


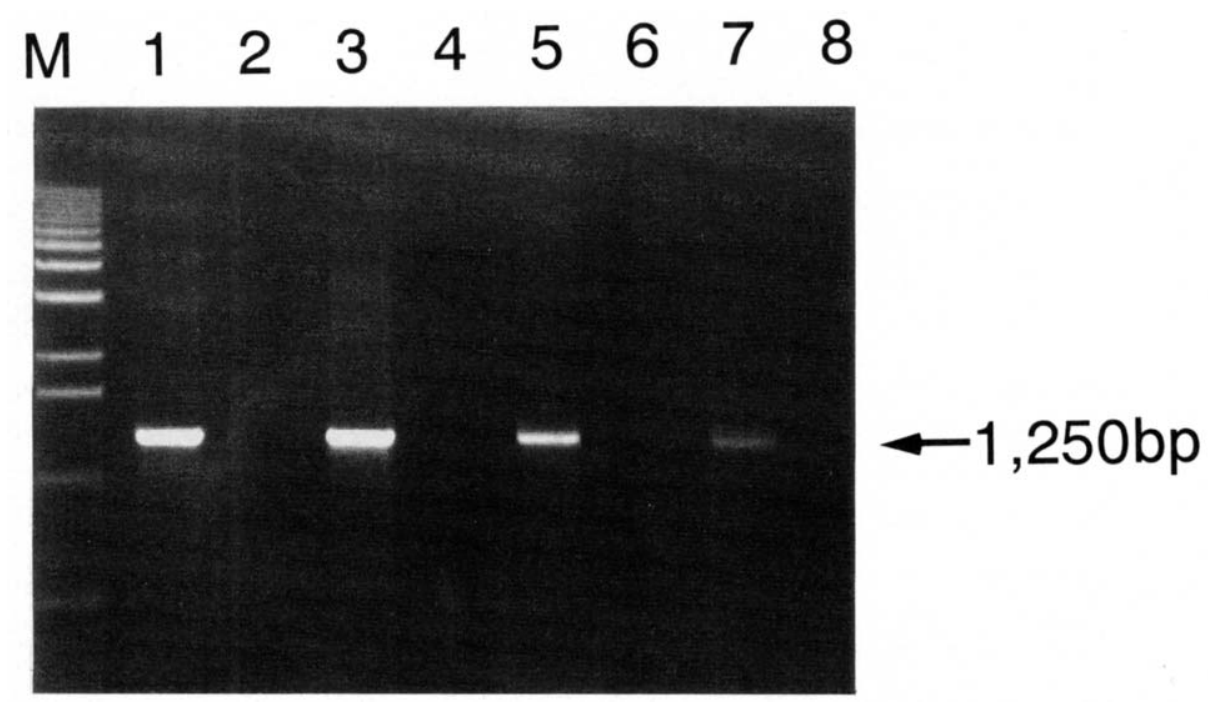

Fig. 3. RT-PCR analysis of CD14 transcripts in several tissues. RT-PCR products were electrophoresed on $1.2 \%$ agarose (TAE buffer) gel. Odd numbered lanes indicate RT-PCR products (approx. $=1,250 \mathrm{bp}$ ) and even numbered lanes indicate the negative control (without RT). Lanes 1 and 2, kidney; lanes 3 and 4, lung; lanes 5 and 6, brain; lanes 7 and 8, liver.

(a)

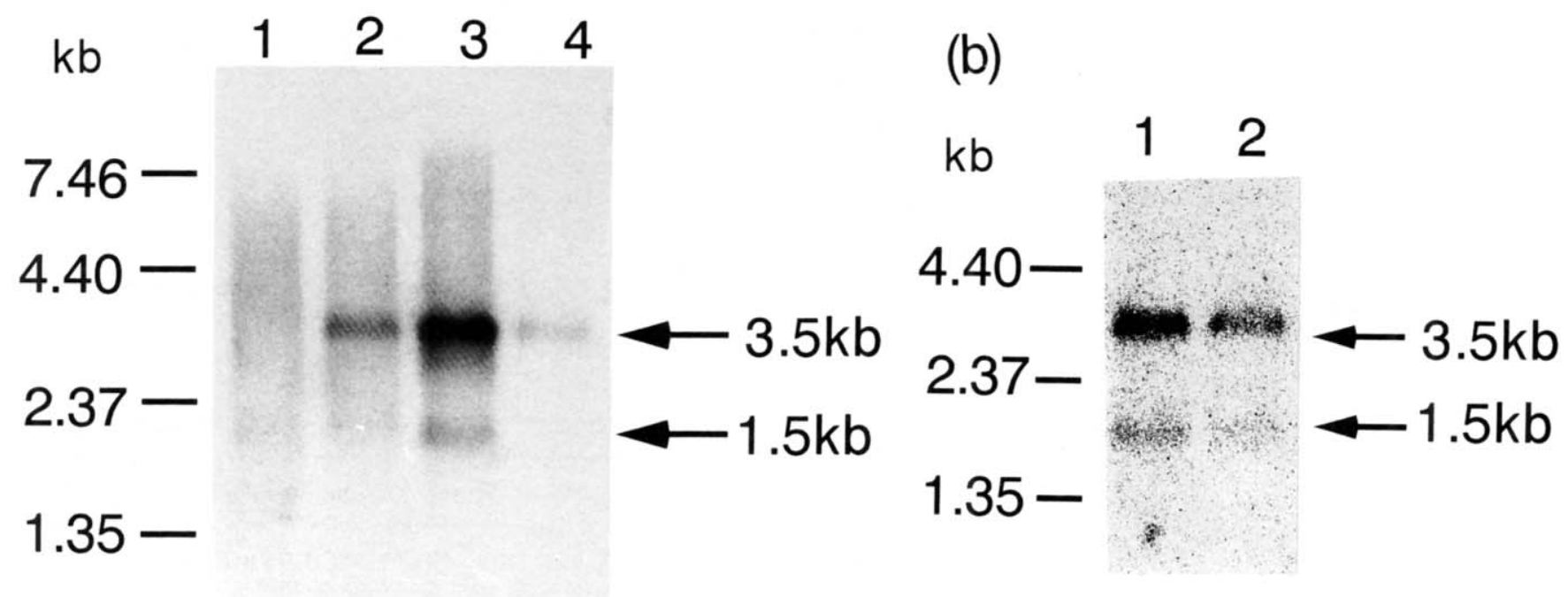

Fig. 4. Northern blots of poly(A)+ RNAs from bovine tissues using bovine CD14 probe (1718 nt-2294 nt). Poly(A) $)^{+}$RNAs were separated on a $1 \%$ agarose gel containing formaldehyde and transferred to a nylon membrane (Geen Screen Plus ; NEN). The RNA on the membrane was hybridized and washed under same conditions as for plaque hybridization. Panel (a) shows Northern blot analysis of the Poly(A) ${ }^{+}$RNAs $(2.5$ $\mu \mathrm{g}$ ) from several tissues; lane 1, liver; lane 2, brain; lane 3, lung; lane 4, kidney. Panel (b) shows Northern blot hybridization of the Poly(A) ${ }^{+}$ RNAs $(1 \mu \mathrm{g})$ from peripheral blood monocytes. lane 1 , with $50 \mu \mathrm{g} / \mathrm{m} l \mathrm{LPS}$; lane 2 , without LPS. 
expression in bovine cells and tissues will facilitate the understanding of endotoxemia and other related diseases of cattle .

ACKNOWLEDGEMENT. This work was supported by grants from Ministry of Agriculture, Forestry and Fisheries and Japan Race Horse Association.

\section{REFERENCES}

1. Dentener, M., Bazil, V., Von Asmuth, E. J. U., Ceska, M., and Buurman, W. A. 1993. J. Immunol. 150: 2885-2891.

2. Ferrero, E. and Goyert, S. M. 1988. Nucl. Acids Res. 16: 4173.

3. Fererro, E., Hsieh, C. L., Francke, U., and Goyert, S. M. 1990. J. Immunol. 145: 331-336.

4. Ferrero, E., Jiao, D., Tsuberi,B. Z., Tesio, L., Rong, G. W., Haziot, A., and Goyert, S. M. 1993. Proc. Natl. Acad. Sci. U.S.A. 90: 2380-2384.

5. Goddeeris, B. M., Baldwin, C. L., ole-Moi-Yoi, O., and Morrison, W. I. 1986. J. Immunol. Methods 89: 165-173.

6. Haziot, A., Chen, S., Ferrero, E., Low, M. G., Silber, R., and Goyert, S. M. 1988. J. Immunol. 141: 547-552.

7. Landmann, R., Knopf, H. P., Link, S., Sansano S., Schumann, R., and Zimmerli, W. 1996. Infect. Immun. 64: 1762-1769.

8. Lee, J. D. 1992. (unpublished) Accession NO. M85233 and
M90488.

9. Lee, J. D., Kato, K., Tobias, P. S., Kirkland, T. N., and Ulevitch, R. J. 1992. J. Exp. Med. 175: 1697-1705.

10. Matsuura, K., Ishida, T., Setoguchi, M., Higuchi, Y., Akizuki, S., and Yamamoto, S. 1994. J. Exp. Med. 179: 1671-1676.

11. Matsuura, K., Setoguchi, M., Nasu, N., Higuchi, Y., Yoshida, S., Akizuki, S., and Yamamoto, S. 1989. Nucl. Acids Res. 17: 2132.

12. Nishijima, M., Hara-Kuge, S., Takasuka, N., Akagawa, K., Setouchi, M., Matsuura, K., Yamamoto, S., and Akamatsu, Y. 1994. J. Biochem. 116: 1082-1087.

13. Raetz, C. R., Ulevitch, R. J., Wright, S. D., Sibley, C. H., Ding, A., and Nathan, C. F. 1991. FASEB J. 5: 2652-2660.

14. Setoguchi, M., Nasu, N., Yoshida, S., Higuchi, Y., Akizuki, S. and Yamamoto, S. 1989. Biochim. Biophys. Acta 1008: 213-222.

15. Simmons, D. L., Tan, S., Tenen, D. G., Nicholson-Weller, A., and Seed, B. 1989. Blood 73: 284-289.

16. Wright, S. D., Ramos, R. A., Tobias, P. S., Ulevitch, R. J., and Mathison, J. C. 1990. Science 249: 1431-1433.

17. Yang, Z., Carter, C. D., Miller, M. S., and Bochsler, P. N. 1995. Infect. Immun. 63: 51-56.

18. Yoo, H. S., Maheswaran, S. K., Lin, G., Townsend, E. L., and Ames, T. R. 1995. Infect. Immun. 63: 381-388.

19. Ziegler-Heitbrock, H. W. L. and Ulevitch, R. J. 1993. Immunol Today 14: 121-125. 